\title{
The 'Host' Label: \\ Forming and Transforming a Community Identity at the Kakuma Refugee Camp
}

\author{
Cory Rodgers \\ Pedro Arrupe Research Fellow in Forced Migration Studies \\ Refugee Studies Centre, \\ University of Oxford, UK \\ cory.rodgers@qeh.ox.ac.uk
}

There is the accepted manuscript of a forthcoming article in the Journal of Refugee Studies. Date of Acceptance: 19 November 2019

DOI: $10.1093 / \mathrm{jrs} / \mathrm{fez} 109$

\section{Acknowledgements:}

Fieldwork was made possible by a seed grant from the Swiss FDFA. The author recognises the Jesuit Refugee Service for funding the Pedro Arrupe Research Fellowship in Forced Migration Studies, under which this article was written. Thanks are due to Alexander Betts, Matt Gibney, Paul White, two anonymous reviewers, and especially Roger Zetter for providing crucial feedback to an early draft. Nina Weaver provided invaluable support during revision. 


\begin{abstract}
In 1986, Robert Chambers argued that refugee-centric responses to displacement tend to neglect the populations that host them. Three decades later, the Comprehensive Refugee Response Framework (CRRF) has made assistance to host communities a matter of high priority for agencies, policymakers, and other stakeholders involved in refugee protection. While recognising the progressive principles of responsibility sharing and inclusivity that underlie this shift, this article calls for greater critical attention to the meaning of the term 'host community' and the ways that it is applied. Taking the Kakuma refugee camps in north-western Kenya as a case study, I describe the rise of a 'host community' identity in the context of humanitarian programming, contested attempts to define it as a bureaucratic label, and its transformations under a socio-economic integration agenda. While the case presented here is specific to Kenya, the argument is relevant more broadly as hosts are brought under the purview of refugee protection policies, especially in countries implementing the CRRF.
\end{abstract}

Keywords: Hosts, Labelling, Camps, Communities, Integration

\title{
Introduction
}

In an early critique of refugee-centric responses to displacement, Robert Chambers lamented that hosts are often a peripheral concern in research and an afterthought in humanitarian programmes. He pointed to a lack of specificity in the definition of the 'host community' as a category, resulting in both ambiguity and assumptions of homogeneity in the ways the term is used:

Hosts have tended to be a residual, thought of as a single entity summarized as 'host communities', 'the people' or 'the surrounding population'... Time and resources have not permitted a special detailed study of the impact of refugees and refugee programs on different groups, least of all on those who are poorer, more vulnerable, less articulate and less seen. (Chambers 1986: 249)

Because the humanitarian system was oriented to the special protection needs of refugees, it tended to overlook and under-prioritise those affected by displacement but not themselves displaced. Moreover, those already marginalised within the host population found themselves in a double jeopardy, as 'hidden losers' within an already neglected demographic.

In the decades since Chambers's critique, researchers have paid greater attention to the plight of host populations (Bakewell 2008). The impact of hosting refugees has been evaluated in terms of socio-economic costs and benefits (Betts et al. 2017; Fiddian-Qasmiyeh et al. 2012; Kuhlman 1990; Tumen 2016), local infrastructure and social services (van Damme et al. 1998), damage to the local environment (Black 1994; Jacobsen 1997), and security (Martin 2005). Others have investigated the longer-term transformative impacts of hosting refugees on governance, statebuilding, and social organization (Jacobsen 2002; Landau 2003; Waters 1999). Beyond research, host communities have featured more prominently in recent refugee policy and programming, most notably in the 2016 New York Declaration for Refugees and Migrants, the two global compacts, and the Comprehensive Refugee Response Framework (CRRF). 
However, while academics and policymakers are paying more attention to hosts, there remains a lack of conceptual scrutiny about the meaning and boundaries of this category and the ways that it is applied. Vaguely associated with qualities like indigeneity and locality, hosts are 'taken for granted as a category that comes into existence when IDPs or refugees arrive' (Brun 2010: 340). Sometimes the distinction between refugees and hosts is blurred, especially in contexts of overlapping displacement in cities and urban camps (Fiddian-Qasmiyeh 2016). But the distinction is reified under rural encampment policies, which require a spatial division of people into refugees and hosts.

Once the refugee-host dichotomy is established - and especially where hosts identify predominantly with one ethnicity - research tends to overlook diversity within the host category and the disparate ways that differently-positioned hosts are impacted by the presence of displaced populations and humanitarian operations (for notable exceptions, see Whitaker 2002; Brun 2003). In this respect, while contemporary research and policy may be less refugee-centric, Chambers's concern about 'hidden hosts' remains pertinent. And as hosts are increasingly brought into the fold of refugee policy and programming, the risks of applying categories uncritically are potentially heightened.

The common-sense conception of hosts contrasts sharply with the decades of politico-legal debate and academic scrutiny over the term 'refugee'. Especially influential was Roger Zetter's early identification of 'refugee' as 'one of the most powerful labels currently in the repertoire of humanitarian concern' (1988: 1). He urged researchers to cast a critical eye at a concept that might otherwise have been taken for granted as obvious and self-evident, especially with the rise of an eponymous field of study. Here, I argue for a similar approach to the term 'host community'. There is no corresponding field of 'Host Studies', nor am I suggesting that there should be. But amidst the increasingly institutionalised inclusion of host communities in refugee protection programming, an analysis of the formation and transformation of the 'host' label directs much needed scrutiny at the assumptions that it imposes, the needs that it implies and the contestations that it conceals.

This paper takes the Kakuma refugee camp in north-western Kenya as a case study of the contextually situated and historically specific emergence of 'host community' as a policy category, the formation of a label from that category, and the transformation of the label under a socio-economic integration agenda. While refugees in Kakuma have been subjected to much research - and arguably over-researched (Omata 2019) - this paper focuses on non-refugees living in the vicinity of the camp. For the historical aspects of this study, I draw on critical discourse analysis of programme reports, funding appeals and other documents from organisations such as UNHCR, Lutheran World Federation, World Food Programme, Action by Churches Together, World Bank, and the International Finance Organisation. Most documents are available either on the organisations' respective websites or on the ReliefWeb online repository. This study also draws on more than two years of fieldwork in Turkana County, which includes a total of 7 months of interviews and ethnographic research in the vicinity of the camp, carried out over multiple visits from April 2016 to January 2019. Most of the time was spent speaking with Turkana residents living at various distances from refugee settlements, including both sedentary households and pastoralists. Interview were also carried out with other Kenyans, 
refugees, and employees of humanitarian organisations.

The first section outlines a conceptual framework based on the labelling literature in Refugee Studies. The next section describes the processes by which the 'host community' emerged as a policy category in Kakuma in the late 1990s amidst programmes to mitigate conflict and promote peaceful coexistence between refugees and locals. The two ensuing sections discuss the processes of label formation and transformation following the establishment of the nearby Kalobeyei Settlement in 2016. First, the introduction of host benefits such as jobs instigated debates about who could claim the 'host' label. Although this remains a point of contention, attempts to define the 'host community' in more clear-cut terms exemplify the politics of label formation where scarce employment opportunities are at stake. Second, the socio-economic integration agenda at Kalobeyei has engendered a transformation of the 'host community' label, imbuing it with an entrepreneurial bias that ignores the needs of the pastoralist majority living in the area.

\section{Labelling}

In order to examine the evolving meanings and practices associated with term 'host community' in Kakuma, I take my lead from a vast literature in Refugee Studies that interrogates taken-forgranted words like 'refugee' (e.g. Shacknove 1985; Zetter 1988), 'forced migrant' (e.g. Richmond 1994; Turton 2003), and 'displacement' (e.g. Malkki 1992; Turton 2005), thereby revealing the 'language games' of international refugee and migration policy within which they are constructed (Chimni 1993). One early study of great influence was Zetter's (1991) application of 'labelling theory' to document the processes that shaped the 'refugee' label as a bureaucratic identity throughout the humanitarian response to the 1974 Turkish invasion of Cyprus. This notion of 'labelling' has been redeployed in later studies on the various and changing meanings and values associated with the 'refugee' label (Inhetveen 2006; Kumsa 2006; Ludwig 2016; Pittaway \& Pittaway 2004), as well as the proliferation of new labels to describe those who might otherwise be deemed refugees (Crawley \& Skleparis 2018; Sajjad 2018; Sigona 2003; Zetter 2007).

This study applies a modified version of Zetter's framework to describe the formation, transformation and politicisation of the 'host' label in Kakuma. The first process formation refers to the ways that labels are created in pursuit of 'managerial objectives' such as identifying beneficiaries, delivering services, and running programmes (Zetter 1991: 49). In the case of Cyprus, the 'refugee' label was used primarily to identify those in need of housing assistance. As such, the meaning of 'refugee' was derived not only from conventional legal definitions, but according to a set of needs related to shelter. Due to a lack of immediately available housing, additional criteria based on vulnerability were derived, further disaggregating refugees into 'poor refugees', 'women refugees' and so on. Importantly, while these imposed labels differ from the ways that people perceive themselves, they nonetheless become a part of people's identity as they are imposed through programme implementation and the distribution of entitlements.

My approach to label formation has been expanded to account for Bakewell's notion of 'policy categorization' as 'one of the core processes in the production of bureaucratic labels' (Bakewell 2008: 436). As an example, Bakewell considers the two-step emergence of 'youth' as a target for 
humanitarian intervention in camps:

The difficulties faced by youths in refugee camps only become apparent if we start looking at the camp with an implicit category of youths. Once the category is established, a set of problems associated with those who fall into it may be identified, and the category becomes a client group for policy, with a stereotypical set of assumed needs. The category of youth is attached to a bureaucratic system and becomes a label. (Bakewell 2008: 436)

This example suggests that 'youth' becomes a policy category when it signifies a group of concern to policymakers. It then becomes a label when it is applied systematically to target individuals who exhibit the characteristic needs of that group and can be included in the relevant interventions. In short, policy concerns give rise to policy categories, and labels are then used in the bureaucratic process of identification. I will apply this two-step conceptualisation of label formation in my case study from Kakuma.

The second labelling process in Zetter's framework is transformation, which describes how over time and through entanglement in multiple agendas - 'the meanings and outcomes of the label refugee assume distinctive yet divergent characteristics' (Zetter 1991: 52). In Cyprus, housing assistance to refugees was undertaken amidst the government's economic recovery efforts. At the juxtaposition of these humanitarian and development agendas, 'one conceptualization of the label - housing need - legitimised the assertion of a rather different one' (ibid.). This economic recovery agenda required mass urban housing, and it 'could only have been achieved by deploying refugees as a structural and spatial resource', including as a labour force for construction and a market for consumer goods (ibid.). Refugees' needs for housing become conflated with the government's aims to boost the housing market, and so the predominantly rural population of refugees was therefore settled in mass urban housing.

Importantly, such transformations may occur without the intention of planners. Once established in bureaucratic practice, 'labels create their own momentum', and they can alter programme outcomes in unanticipated ways (Zetter 1991: 80). As Ferguson warns about development institutions, 'intentional strategy is not taken for granted', for there is often a 'subjectlessness' in the exercise of power by institutions that are themselves distributed networks of knowledge and agency (Ferguson 1994:18-19).

Zetter's framework also includes a third process, politicisation, in which those labelled as refugees use their status to political ends, often with repercussions for the values associated with the label itself. However, in the case of Kakuma, politicisation is not a separate process, but rather an aspect of label formation and transformation. For one, labels that determine access to resources or entitlements are often intractably political. Second, and with particular relevance to host populations, nationals with access to their citizenship rights are less susceptible to the topdown imposition of labels by humanitarian actors.

While labelling 'theory' has informed much valuable research in Refugee Studies, it has been critiqued for its lack of conceptual and theoretical specificity. Cole (2017: 5) points in particular to the lack of attention to the role of language, which is crucial to understanding the dual qualities of consistency and malleability required for a label to take on multiple and changing 
meanings, while remaining relevant and recognisable for policymakers and practitioners. Drawing on semiotic theory, she argues that the 'refugee' label should be treated as a sign with multiple orders of meaning. The first order focuses on the legal definitions provided in the various conventions and protocols, thereby providing a widely recognised bedrock of legitimacy that sustains the term's currency. However, 'refugee' also emerges as a range of second-order signs that draw relations between the first-order sign and various other connotations, which reflect the agendas and interests of different actors or the prevailing concerns of the time. It is at the second-order level that refugees come to be seen as a security threat, or an economic burden, or as helpless victims of violence. An important implication of this tiered semiotic model is that new layers of meaning distort and distance the first-order meanings, but they do not erase or remove them:

Over time and in entering different spaces, individuals may seamlessly 'slide' between the different orders of meaning due to personal circumstance, political intent and sociohistorical conditions. The first-order sign is always there to be drawn upon opportunistically to favour a particular politics or policies. (Cole 2017: 7)

The conceptual approach used here incorporates this semiotic elaboration while maintaining Zetter's attention to the processes of formation and transformation, which remain useful in describing a contextually-situated, historically-specific account of labelling. In the sections to follow, I describe the emergence of 'host community' as a policy category in the context of the security agenda at the Kakuma refugee camp, its contested formation as a label to determine access to host entitlements and opportunities, and the transformation of the label as refugees and hosts have become part of the socio-economic integration agenda at the Kalobeyei Settlement.

When using a case study to deconstruct labels and categories, one challenge is to differentiate between the sign (often a word) and its referent (the thing the word designates). To draw attention to signs, I will use apostrophes (e.g. the 'refugee' or 'host' labels, rather than the people to whom those labels are applied). A more frustrating challenge is to avoid reifying the very categories that I intend to deconstruct. As will become clear, it is my argument that the 'host community' is a convenient fiction with implicit assumptions about internal organisation and common ownership, and so I will not use this term except in reference to the abstract sign. When referring to actual groups of people, I will use categories such as 'Kenyan nationals' and 'local population' that presume only an aggregate of people and not relations among them. Ethnic categories are similarly contentious. Turkana people refer to themselves collectively as ng'iturkana, and so I will also apply this word to distinguish ethnic self-identification from imposed categories, such as 'the Turkana community'.

\section{'Host Community' as Policy Category in Kakuma}

Over the past two decades, UNHCR and its implementing partners in Kakuma have had to contend with clashes between Turkana locals and the refugees who have been placed on their land. The prevailing responses have been to promote peaceful co-existence and to include Turkana people in camp services. In this way, the term 'host community' became regularised as a policy category in Kakuma, which - as described in the next section - provided the basis for its formation as a label. 
Of course, the word 'hosts' was already part of the humanitarian lexicon long before UNHCR established the Kakuma refugee camp. Jonsson (2016: 13) identifies the ICARA conferences of the 1980s as the first instances in which 'host communities' were discussed in terms of the burdens placed on them by refugees and aid operations. However, the term was in circulation even earlier in both sub-Saharan Africa (Gould 1974) and South-East Asia (Rambo et al. 1967), in relation to both the impact of refugees on local populations and the ability of those populations to absorb them. When Kakuma was established in 1992, the term 'hosts' generally referred to the Turkana people who lived around the camp and who constituted an almost ethnically homogenous population across the 75,000 square kilometres of Turkana County. However, the emergence of the 'host community' as a policy category in Kakuma was a contextually-situated and historically-specific process.

Kakuma is located in the arid north-western plains of Turkana County, near Kenya's borders with South Sudan and Uganda. The name is shared by the refugee camp, the neighbouring town, and the administrative ward that encompasses both. The word Kakuma is derived from the Turkana language, the speakers of which claim the county as their ethnic homeland and make up the vast majority of its population. Many $n g$ 'iturkana live frugal lifestyles as transhumant pastoralists, moving their homes and herds according to seasonal changes and in search of grass and browse for their livestock. The dryland plains surrounding Kakuma - which outsiders see as a desolate and hostile environment - have given it a reputation as an unwelcoming place. But for herders, Kakuma was historically an important wet season grazing ground, where the Tarach River fed sorghum gardens during its annual floods and provided shallow wells (ng'akar) for long after.

Like most urban centres in Turkana County, Kakuma town was established as an administrative outpost during the colonial era, a sedentary speck in an otherwise nomadic landscape. After Independence, the Catholic Church founded a missionary centre in Kakuma, where they built Turkana's first hospital and operated a famine camp for drought-affected pastoralists. The population of Kakuma swelled following droughts as diminished herds became unable to support large families, but many re-joined their relatives when conditions improved and livestock were again reproducing. The modest cohort of settled urbanites consisted largely of employees of the Church, including a small demographic educated in the mission schools. A goldrush in Nadwat, about $50 \mathrm{~km}$ south-east, encouraged further immigration to Kakuma. But the population remained small - estimates vary from 2,000 to 8,000 people (Jansen 2018: 16) - until the start of refugee operations in 1992.

That year, nearly 30,000 people arrived in Turkana from southern Sudan, many of them unaccompanied minors officially aligned with the rebel Sudanese People's Liberation Army (SPLA). UNHCR established a refugee camp in Kakuma, and over time the South Sudanese residents were joined by refugees from Somalia, Ethiopia, the Great Lakes region, and elsewhere. The camp yielded benefits for some $n g$ 'iturkana living in Kakuma. Locals could access free refugee protection services provided by UNHCR, including medical care and education. The humanitarian industry attracted people from across the district and from farther abroad in Kenya. Within 15 years, the population of Kakuma town had grown to at least 50,000, a roughly 10-fold increase from 1992 (Jansen 2018: 16). Some people sought employment with agencies, and others pursued entrepreneurial opportunities offered by the growing camp economy. The camp also provided a means of survival for destitute pastoralists whose herds had 
been decimated by drought, livestock disease, and cross-border cattle-rustling. Many moved to town or to small settlements adjacent to the camp, where they were employed to perform domestic tasks such as washing clothes and collecting water, sometimes by refugees. Others collected firewood and produced charcoal for sale in the camp.

However, UNHCR's food assistance did not extend to $n g$ 'iturkana or other local Kenyans, a point that raised ire among food insecure locals in Kakuma. From 1992-1998, UNHCR had focused solely on refugees in Kakuma while aid to the surrounding population was largely undertaken by the Government of Kenya (GoK), Catholic Church, World Food Programme (WFP), and INGOs. But Turkana people's food aid was provided only during periods of drought, and they could not rely on recurring monthly rations like refugees. Many locals asked 'what makes "aliens" special compared to other nationals who opt not to flee despite facing the same circumstances?' (Aukot 2003: 75). UNHCR was accused of giving refugees better living standards and access to services than citizens, a sentiment that has also been expressed by people living near refugee settlements in Tanzania (Armstrong 1988) and Uganda (Orach \& de Brouwere 2004). This was compounded by concerns about rapid deforestation, occasional clashes with Turkana people, and concerns that refugees were undermining the local bridewealth system by failing to adhere to Turkana marriage rules.

Food relief was one of the first points where the strict separation between refugee protection and Turkana food aid was blurred. In December 1998, GoK invited the Lutheran World Federation (LWF) - UNHCR's lead implementing partner in Kakuma - to carry out community-based targeting and distribution of food to Turkana beneficiaries in their drought response operations. LWF found itself in a unique position as a provider of services to both refugees and $n g$ 'iturkana, which engendered an early operationalisation of the 'host' category. In the 1998 aid appeal for camp operations in Kakuma, the only mention of Turkana people was as local pastoralists who would not tolerate refugees competing for scarce grazing resources. ${ }^{1}$ However, by 2002, LWF saw its involvement 'in both refugee and host community relief and development assistance' as 'a great opportunity to enable the bridging of hosts-refugees inequalities, promoting peaceful coexistence and co-operation'. ${ }^{2}$

LWF's efforts at bridge-making overlapped with an increasing recognition that Turkana discontent could threaten the security of camp operations in Kakuma. A review of the Kakuma operations conducted by UNHCR's Evaluation and Policy Analysis Unit (EPAU) points out that anger over the negative impacts of refugees on local populations had become 'a regular feature on the UNHCR Executive Committee' and warns that some level of engagement with hosts is advisable: 'UNHCR is not responsible for them. But as the most influential agency in the region, it is aware of their plight and, in a worst-case scenario, vulnerable to their threats' (Jamal 2000): 29). Occasional conflicts broke out between refugees and Turkana, including a particularly deadly clash in 2003 that resulted in 12 deaths and the displacement of 30,000 people within the camp. ${ }^{3}$ Coverage of these events led to recognition of the marginalised position of Turkana people in Kakuma, as well as the risk that they posed to aid operations. In the 2003 appeal for funds, LWF explained:

Since the camp was established, there have always been isolated banditry attacks in the camp. However, the magnitude of violence and tension in 2003 had never been seen. It led to loss of 12 lives and displacement of refugees within the camp. From 2001, a total of 22 
lives have been lost in protracted conflicts between the refugee and the host communities. ${ }^{4}$

Due to this security threat, the 'host community' emerged as a group of concern for refugee operations in Kakuma. It became a recurring focus of humanitarian programmes aimed at promoting peaceful coexistence, as well as a popular topic of academic research, with many students writing their dissertations on host-refugee relations in Kakuma (e.g. Grindheim 2013; Jonsson 2016; Tureti 2003). The popularity of hosts as a research topic may suggest that it served not only as a policy category but also as an analytical category. However, Bakewell distinguishes analytical categories by the sustained scrutiny with which they are applied by researchers, who 'can review their categories of observation in their analysis' (2008: 436). Such scrutiny was exercised only on occasion: for example, the author of the EPAU report expressed scepticism about the idea of a 'host community' in Turkana, where he observed that 'locals do not "host" the refugees in any meaningful way' (Jamal 2000: 27). But most of the researchers cited above began their studies with the premise that 'hosts' was a category of policy concern and therefore a valuable topic for research; its descriptive accuracy was rarely questioned.

\section{From Policy Category to Contested Label}

It is clear from the preceding section that the 'host community' has become an important policy category for humanitarian practice in Kakuma. But is 'host' really a label? As described by Bakewell (2008) and reviewed above, categories become labels when they are deployed in a bureaucratic system to identify targets for intervention. Based on this definition, the peacemaking and conflict mitigation programmes in Kakuma do entail some degree of labelling, but mostly for refugees. Kurimoto (2009: 224) describes how concerns about inter-communal violence in Kakuma spurred the disaggregation of southern Sudanese refugees into Dinka, Nuer, and Equatorians, an awkward typology blending geography with ethnicity, and with little attention to the complexity of political history and affiliations in Sudan. But for the 'host community', there was little fine-grained disaggregation. It was taken for granted that anyone living outside the camp was Turkana, and so Turkana become a rough equivalent for 'host'.

However, in 2015 UNHCR started construction of the Kalobeyei Settlement, which aimed to foster socio-economic integration as an alternative to the conventional encampment model of refugee protection. This entailed significant entitlements for the 'host community'. Located just 20 kilometres west of Kakuma town, Kalobeyei was billed as an integrated settlement where refugees and hosts would live together, access joint services, and use shared infrastructure. Perhaps most importantly, it was intended to promote self-reliance for both refugees and hosts through employment and business opportunities.

Employment was a key point of contention in negotiations for the land on which the settlement would be constructed. In order to acquire access to the land, the UNHCR Country Director signed a Terms of Engagement (ToE) with local representatives in February 2015, which specified that 70 percent of job opportunities associated with the settlement would be provided to the 'host community'. There were also business opportunities associated with the turn to cashbased assistance. One of the flagship programmes in Kalobeyei is Bamba Chakula ('Get your Food' in Swahili). Rather than receiving in-kind food direct from the World Food Programme 
(WFP), refugees receive a monthly voucher that they can use to buy food from selected retailers, who would in turn benefit from the new consumer market. Each month, the programme distributes a total of about 500,000 USD to refugees in Kalobeyei, so a retailer contract provides access to a sizeable market. In 2016, WFP called for expressions of interest from prospective refugee and host retailers to receive Bamba Chakula contracts. A similar initiative is UNHCR's Cash for Shelter programme, which provides monetary transfers to refugees in Kalobeyei, who can then hire local contractors to provide the materials and labour needed to build houses. Both employment and business opportunities were intended to provide incentives for locals to accept the expansion of refugee protection operations to the new site.

However, the designation of host-specific opportunities risked inciting ethnic conflict in Kakuma, where the town population includes a sizeable and influential minority of non-Turkana Kenyans, whom $n g$ 'iturkana sometimes describe as $n g$ 'imoe ('outsiders'). UNHCR and its implementing partners also employ a substantial number of non-Turkana Kenyans as national staff. To pre-empt conflict, there were early attempts to formalise an inclusive notion of 'host community'. When the WFP contracted host entrepreneurs as Bamba Chakula retailors in Kalobeyei, it included a number of non-Turkana Kenyans. Additionally, a proposed amendment to Kenya's Refugee Act submitted to the National Assembly in 2015 provided a geographic definition, stating that 'host community means a citizen residing within $80 \mathrm{~km}$ radius from the outer perimeter of an area designated as a refugee camp'. While the bill failed to pass for other reasons, the drafting of a specific definition of 'host community' departed from the earlier assumption of an easy equivalence between 'host' and 'Turkana'.

Contrary to this non-ethnic geographic definition, many ng'iturkana saw the 'host community' as an ethnically-bounded group, which would ensure that host entitlements - including job opportunities and Bamba Chakula contracts - are not allocated to $n g$ 'imoe from elsewhere in Kenya. This ethnic designation was already enshrined in the ToE, which was signed by representatives of the 'Turkana / Host Community'. If there is any question of whether Turkana refers to ethnicity or simply a geographic area (Turkana County), the ToE specifies that signatories will 'respect and preserve host community culture and way of life', implying a culturally defined group rather than a more cosmopolitan national identity.

Some non-Turkana Kenyans are also uncomfortable being designated as 'hosts' due to their own sense of outsider-ness in Turkana. James, a man from central Kenya, has opened a hoteli (a small restaurant) in the market area of the Kalobeyei Settlement. His establishment serves typical Kenyan fare like chapatis, bean stews, and mandazi donuts, and it is frequented by agency employees, construction teams, and police officers, as well as refugees and herders who can afford it. On one occasion when I sat down to a coffee in his hoteli, an Equatorian refugee entered and requested food from a Turkana customer, who was taking tea before starting work as a security guard at a nearby school. The two argued across their respective languages, which are close Nilotic relatives, but which James could not understand. James eventually intervened on behalf of his customer, politely escorting the refugee man outside. The ejected man protested, but another Turkana man stepped over and told him not to cause a scene.

When James returned, I asked if he often encounters such problems. He responded that he generally has good relations with hosts, who assist him when needed. While, as a Kenyan, James 
would be part of the 'host community' in its broadest national sense, he uses the term to refer to locals who are more connected with the refugees than himself. Indeed, Nilotic-speaking refugees from Eastern Equatoria in South Sudan are more linguistically related to Turkana-speakers than to Bantu-speakers like James from Kenya's agricultural highlands. For cosmopolitans such as James, hosts and refugees are both part of an exotic 'other; who come together to form 'the local' in Kalobeyei.

In one of the most exclusionist examples of label formation, some $n g$ 'iturkana have argued that the 'host community' should be restricted not just to their ethnic group, but to those who belong locally to Kakuma and Kalobeyei. Claims to belonging draw on customary principles concerning territory, kinship and land tenure. Most people identify with one of the broad territorial section into which Turkana is customarily divided, for which the colloquial translation is "sub-tribe". At a more fine-grained level, a family will make claims to a particular area as their ere, which may be the place where they were born and raised or the area to which they return during the wet season, or to a section of riverbank known as an ekwar, which is where a family grows their seasonal sorghum. Such customary notions of belonging are fluid, contestable, and subject to deliberation by local elders.

However, when subjected to bureaucratic labelling processes, belonging becomes not an ongoing negotiation over an eternally contested construct, but an institutionalised feature of bureaucratic 'reality'. Ng'iturkana who have come to Kakuma seeking jobs from elsewhere in Turkana County are labelled derogatorily as fuata lami ('those who follow the tarmac'), a reference to the stretch of highway cutting through Kakuma. This was long the only paved road in the county, a symbol of UN presence and the opportunities afforded by the camp. Residents of Kalobeyei have suggested that the 'host community' should be limited to those with national I.D. cards registered in their location (an administrative unit beneath the sub-County). This definition for the host label clashes with the proximity-based definition proposed in the 2016 Refugee Bill. Whereas the designation of 'hosts' according to geographic radius around Kakuma and Kalobeyei would have institutionalised a non-ethnic criterion of residency, the turn to I.D cards instead promotes an ethnic - and even intra-ethnic - criterion based on place of birth.

As these examples show, the 'host community' emerged as a policy category in response to security concerns in Kakuma. It has more recently been subjected to processes of label formation due to the availability of host entitlements in Kalobeyei. Label formation involves making categories more 'clear-cut' and therefore useful in identifying who will be included in versus excluded from benefits (Zetter 1991: 44). This mirrors debates over belonging described elsewhere in Africa that involve the rise of exclusionary definitions of citizenship, often involving the imposition of dichotomous labels such as 'foreigner' and 'citizen' (Whitaker 2005). Claims to indigeneity, autochthony and other belonging are usually contested, and studies have described how 'any attempt to define the autochthonous community in more concrete terms will give rise to... disagreements' (Geschiere 2009: 27). The political nature of that process suggests label formation will remain a point of contestation, exceeding UNHCR's ability to impose labels and define boundaries.

Nonetheless, label formation does allow categories to take on a property of taken-forgrantedness, such that they 'develop their own rationale and legitimacy' (Zetter 2007: 180). As 
described below, this is exemplified in the ways that UNHCR and the World Bank instrumentalised the 'host community' label to build enthusiasm for its socio-economic integration agenda, thereby engendering an urban-entrepreneurial transformation of the label.

\section{Entrepreneurial Transformations Under Socio-Economic Integration}

As described in the previous section, the Kalobeyei Settlement was designed as an alternative to the 'care and maintenance' model that is typical of camps, instead promoting socio-economic integration through programmes like Bamba Chakula and Cash for Shelter. Aside from business and employment opportunities for beneficiaries, the Turkana County Government envisions the settlement as a source of regional economic stimulation and tax revenue, and international organisations have promoted the self-reliance strategy to donors as a means to cut long-term aid costs. As such, both governmental and international actors have been keen to build support for the socio-economic integration agenda. Insofar as it designates one half of the target population for integration, the 'host community' concept has been indispensable in this regard.

Importantly, the word 'community' carries connotations that were latent in earlier references to the 'host community' category in Kakuma. In the older security discourse, 'host community' was used interchangeably with 'host society' and 'host population', all referring vaguely to people living in the vicinity of the camp. These categories suggested little more than an aggregation of people. But the word 'community' is also used in a communitarian sense to refer to 'selfcontained, fairly homogeneous groups' (Delanty 2003: 91). This communitarian depiction mischaracterises the diverse demographics of and relations among the people living in Kakuma and Kalobeyei. Some people in Kakuma town and the other settlements along the main highway are no longer involved in pastoralism. They pursue employment with aid organisations as well as low-skill employment opportunities in or around the camp. However, many people in the rural areas continue to rely on livestock husbandry for their livelihoods, supplemented by sale of firewood, charcoal, or other goods that can be collected and sold in Kakuma. Few from this demographic have attended school, and many speak neither English nor Swahili, leaving them unqualified for most employment or trade opportunities. In the Turkana language, this latter group refers to themselves as raiya, to distinguish themselves from urbanites.

This raiya vs urban division is largely obscured by the 'host community' label. In 2016, UNHCR and the World Bank published the results of an economic and social assessment that measured the impact of the camp on the local population in Kakuma. The findings were pitched to set the stage for the socio-economic integration agenda in Kalobeyei. Research included quantitative measurements of inter alia nutrition, assets, employment, income, and nutrition, as well as qualitative insights from social scientists well acquainted with Kakuma. The economists also ran simulations to model the effects of several scenarios, including ongoing encampment (the status $q u o$ ), refugee integration, and decampment (basically refoulment). Their work culminated in several reports and working papers (Alix-Garcia et al. 2017; Sanghi et al. 2016; Vemuru et al. 2016), as well as a number of peer-reviewed articles (Alix-Garcia et al. 2018; Gengo et al. 2017). These studies have been cited widely as evidence that host countries and communities like Kenya could benefit economically by reducing restrictions on refugee movement and employment, and they also offered an encouraging outlook on plans for the Kalobeyei Integrated Settlement (Mazou 2017). 
The reports and academic papers recognise the diversity of demographics in Kakuma among both the refugee and host populations. The primary synthesis report devotes an entire section of its methods chapter to problematise the notion of 'impact' and accommodate 'the complexity of the problem... since refugee arrivals have different effects on market outcomes and on welfare of different host community groups' (Sanghi et al. 2016: 18). The findings on economic impact are summarised under a section titled 'Winners and losers: A complex and nuanced picture emerges', which explains that while the camp has stimulated the farming and housing sectors, the overall impact on livestock producers is summarised as negative due to increased theft, fewer animals, and reliance on middle-men (ibid.: 44). This recognition of both winners and losers is repeated in the background working paper (Alix-Garcia et al. 2017: 3).

However, the 'host community' label ultimately erases this nuance. Despite acknowledging winners and losers, the background working paper summarises its findings under the heading 'the host community of the Kakuma refugee camp benefits from the refugees' (Alix-Garcia et al. 2017: 3). The lead economist for the study has coined the term YIMBY ('Yes in My Back Yard') and taken Kakuma as a quintessential example (Sanghi 2015). Later, in the lead up to a Kakumabased TEDx event, UNHCR Spokesperson Melissa Flemming summarised the World Bank's findings to Al Jazeera: 'We now have the reports... that prove, actually, that the economy has grown, and that everybody is benefiting from refugees' (The Stream 2018).

Another report commissioned by IFC and titled 'Kakuma as a Marketplace' takes this a step further, defining the scope of its study with an explicitly urban limitation:

As the study is looking at the area from the private sector perspective, it is practical to compare the stationary, urban, and densely populated area of town with the stationary, urban, and densely populated camp (International Finance Corporation 2018: 11).

Market activities target those sedentary households engaged in trade and employment. The report describes financial and technical support 'to individual refugees and members of the host community' (ibid.: 79-80), but this support targets owners of small and medium enterprises, rather than the livestock-based livelihoods of the pastoralist majority.

In their report, the IFC is explicit about their circumscribed focus on an urban, entrepreneurial sub-group. But the meaning of 'host community' has been distorted as those applying the label 'slide' between the different orders of meaning (Cole 2017: 7) - one circumscribed and the other implicitly all-encompassing - and livestock-dependent families have increasingly been excluded from discourse. For this reason, much of the optimism about the new Kalobeyei Settlement has ignored the plight of pastoralists. A Reuters article titled 'Kitchen gardens cultivate bond between refugees, Kenyan hosts' describes the growing business relationships between refugees and their Turkana neighbours in Kalobeyei (Rioba 2017). But the article refers to sedentary host households trying to make a living through the cash economy, rather than herders relying on livestock in the surrounding area. During interviews in 2018, I asked Turkana respondents who they felt was benefiting in Kakuma: urbanites or raiya? The responses were almost unanimous:

The people of town (ng'itunga lua arek) are the ones who have an opportunity in Kakuma. 
They are educated, they are employed in jobs, and it is they who have money for doing business (Turkana woman, Naabek resident, near Kakuma camp, interview, December 2018)

Those in town benefit because of the pen, but as for us, we must struggle to sell our firewood. Or some might decide to go get married to a man from town. (Turkana woman, resident of Kang'ageteiberu, near Kalobeyei settlement, December 2018)

While 'people of the government' (i.e. urban) and 'people of the pen' (i.e. literate) are taking advantage of self-reliance programmes, the raiya majority feel left out of these opportunities. Despite the heavy reliance of many Turkana people on livestock, support for pastoralist livelihoods has been minimal. It is noteworthy that while the Kalobeyei Integrated SocioEconomic Development Plan (KISEDP) lists projects to support both livestock-based and agricultural livelihoods, all of the key indicators of progress relate to horticulture, farming and silviculture (UNHCR 2018: 74).

One implication of this urban bias is that it has influenced notions of representation for the 'host community'. As noted earlier, negotiations for the land to build the settlement led to the signing of a ToE between UNHCR, County Government, and host representatives. However, these representatives were accused by raiya locals of consulting primarily with the urban population:

They do not meet with us. What they do is to travel to the centre at Lopeterega and take the chief, the Member of County Assembly, and a few people, and those are the people who give away the land. They don't consult everyone. Then, the locals here in Natukobenyo hear about it a few days later. We wake to find refugees in our land. (Turkana man, Natukobenyo resident, focus group discussion, August 2017)

The people who had previously lived on Natukobenyo with their goats complained that their land was given away because they were not consulted by those who claimed to represent 'the host community'. This left them with nowhere to turn when they attempted to appeal the decision about the settlement. The same man explained, 'When we approach the chief in Lopeterega, he refers us to the chief in Lochor Edome. And when they go there, the chief of Lochor Edome refers us back to the chief in Lopeterega. And now we don't know where to take our problems'.

The assumption of a 'community' is useful to planners and programme implementers - as well as politicians - in that it flattens the complex population living around Kakuma and Kalobeyei and infers that there are representatives who could speak on its behalf. This is a political formulation in which community implies 'citizenship, self-government, civil society and collective identity', which have become important aspects of 'a quasi-governmental discourse' under neoliberal policies (Delanty 2003: 3, 88; Rose 1999). But my interviews suggest that many of the chiefs represent urban groups, as reflected in the high priority of employment opportunities in negotiations. Raiya people, on the other hand, are silenced under the blanket application of the 'host community' label.

\section{Conclusions (Labels, Legibility, and Hidden Hosts: Seeing like an Agency)}


In 1986, Robert Chambers argued that refugee-centric approaches to displacement ignore the people who receive displaced populations in their home places. But 'host communities' are now a priority category in refugee protection programmes, as enshrined in the Grand Bargain at the World Humanitarian Summit as well as the CRRF. While this is undoubtedly a progressive shift toward polices that experts have advocated for decades (Crisp 2001), it also warrants scrutiny of the categories and labels applied to realise this objective.

In this paper, I have argued that policies and programmes institutionalising host inclusion are subjecting 'host community' identity to processes of formation and transformation similar to what Zetter described for the 'refugee' label. In Kakuma, the 'host community' emerged as a category of concern for UNHCR's security agenda, and it was later subjected to increasingly exclusive labelling practices due to the introduction of 'host' entitlements. This has been political from the start, suggesting that politicisation is a dimension of the formation of the label, rather than a separate process. To some degree, however, the more recent transformation of the label under the socio-economic integration agenda has rendered some segments of the Turkana population invisible, thereby excluding them from politics. Specifically, the discourse on the Kalobeyei Settlement has applied an urban, entrepreneurial conception of the 'host community'. This definition may have been justified in the context of economic impact assessments and market studies. But as Zetter described for the 'refugee' label in Cyprus, 'one conceptualization of the label... legitimised the assertion of a rather different one' (1991: 52). This urban bias has justified reliance on 'host community' leaders who cannot reflect the interests of all $n g$ 'iturkana, such that raiya people feel unrepresented and excluded from negotiations.

The processes of formation and transformation that shape the 'host' label differ in some ways from those described for the 'refugee' label. Zetter emphasises 'the extreme vulnerability of refugees to imposed labels' and 'the non-participatory nature and powerlessness of refugees in these processes' (1991: 39). This is especially important in crisis contexts, where 'the modes of designation occur rapidly, in traumatic and unfamiliar circumstances' (ibid.: 60). The 'host community' label in Turkana, on the other hand, has been formed in a protracted encampment context. As a result, attempts by humanitarian agencies to impose a top-down, depoliticised definition have been frustrated by the enduring politics of belonging among locals.

Nonetheless, the description of 'host' labelling presented here suggests two significant contributions to more general discussions of labels in refugee studies. First, the formation of labels does not always result in more detailed definitions or more clearly delineated boundaries. While the introduction of certain host entitlements in Kalobeyei instigated attempts to delineate who was and was not a 'host', the notion of the 'host community' is useful precisely because it is vague, thereby rendering a messy situation comprehensible and open to intervention. It allows World Bank and its partners to make sweeping claims about impacts by moving between the idea that 'some hosts benefit' to the idea that 'the host community benefits'. Vagueness and ambiguity can be useful, insofar as different actors can use the label as 'a shared point of reference to "hide" behind' while pursuing their own - sometimes contentious - agendas (Cole 2017: 16). But over time, signs may come to operate independent of their original referents, such that the label is used in a manner 'that may have no clear relationship to any 'realities' on the ground' (ibid.: 9). This resonates with Scott's notion of legibility, which describes how planners dealing with a complex reality 'reduce the complexity to manageable dimensions', entailing 
some (and often significant) simplification that can overlook crucial aspects of reality (1998: 22). This case study has demonstrated how the 'host community' label has obscured differences based on livelihood, but future research might highlight how it overwrites other intersectional characteristics, including class, gender, race and ethnicity.

Second, and relatedly, community-level labels may influence community-level identity, much in the way that individual-level labels like 'refugee' influence refugee identity. The existence of communities in camps has been recurring point of debate in refugee studies. Hyndman (2000: 139-143) argues that communities are a misnomer in contexts of containment, reflecting UNHCRs' attempts to promote refugee self-management. But Sigona (2003) argues that labels and policies that identify a group and allocate resources to it may effectively create a community. Bulley (2014: 74) takes this a step further by arguing that the instrumental production of refugee communities as a form of governance will always produce 'counter conducts' that exceed instrumental articulations of community. This case study from Kakuma highlights how, indeed, labels allow for the convenient creation of communities to suit the needs of labellers. This transformation is useful not only to bureaucrats but to aspiring community representatives, who can claim to speak for an entire policy category on the basis of membership to an imagined political body.

When Chambers criticised refugee-centric responses to displacement for ignoring host populations, he observed that the consequences are worst for the poorest and most marginalised within those populations. Now, over thirty years later, the heavy emphasis on host inclusion in the 2016 New York Declaration is an acknowledgement that humanitarian responses to displaced populations often fail to address the interests and concerns of displacement-affected populations. However, insofar as the term 'host community' has become common currency in refugee response programmes around the world, research on responsibility sharing, integration, socioeconomic inclusion, and other relevant topics should critically interrogate the ways that this term is conceived as a category and applied as a label.

\section{Notes}

1 'Appeal for Kakuma Refugee Assistance Program: AFKE-83',1998, available on ReliefWeb at https://reliefweb.int/report/kenya/appeal-kakuma-refugee-assistance-program (accessed 9 July 2019).

2 'Appeal for Turkana Famine Relief: AFKE-22', 2002, available on ReliefWeb at https://reliefweb.int/report/kenya/act-appeal-kenya-turkana-famine-relief-afke-22 (accessed 9 July 2019).

3 'Marginalised Turkana Vie with Refugees', IRIN News (now The New Humanitarian), 22 July 2003, available on ReliefWeb at https://reliefweb.int/report/kenya/kenya-feature-marginalisedturkana-vie-refugees (accessed 9 July 2019).

4 'Refuge Assistance in Kakuma - AFKE-41, 2004, available on ReliefWeb at https://reliefweb.int/report/kenya/act-appeal-kenya-refuge-assistance-kakuma-afke-41 (accessed 9 July 2019) 


\section{References}

ALIX-GARCIA, J., WALKER, S., BARTLETT, A., ONDER, H. and SANGHI, A. (2018) 'Do Refugee Camps Help or Hurt Hosts? The Case of Kakuma, Kenya', Journal of Development Economics 130, pp. 66-83.

ALIX-GARCIA, J., ARTUC, E. and ONDER, H. (2017) The Economics of Hosting Refugees: A Host Communty Perspective from Turkana. Washington DC.

AL JAZEERA ENGLISH (2018) The Stream, 7 June. Available on Youtube, https://www.youtube.com/watch?v=S3nj38zTQKs (accessed 21 June 2018).

ARMSTRONG, A. (1988) 'Aspects of Refugee Wellbeing in Settlement Schemes: An examination of the Tanzanian case'. Journal of Refugee Studies 1(1): 57-73.

AUKOT, E. (2003) "“It Is Better to Be a Refugee Than a Turkana in Kakuma”: Revisiting the Relationship between Hosts and Refugees in Kenya'. Refuge 21(3): 73-83.

BAKEWELL, O. (2008) 'Research Beyond the Categories: The Importance of Policy Irrelevant Research into Forced Migration'. Journal of Refugee Studies 21(4): 432-453.

BETTS, A. BETTS, A., BLOOM, L., KAPLAN, J. and OMATA, N. (2017) Refugee Economies: Forced Displacement and Development. Oxford: Oxford University Press.

BLACK, R. (1994) 'Environmental Change in Refugee-Affected Areas of the Third World'. Disasters 18(2): 107-116.

BRUN, C. (2003) 'Finding a Place: Local Integration and Protracted Displacement in Sri Lanka'. PhD thesis, Norwegian University of Science and Technology NTNU Trondheim.

BRUN, C. (2010) 'Hospitality: Becoming IDPs and Hosts in Protracted Displacement'. Journal of Refugee Studies 23(3): 337-355.

BULLEY, D. (2014) 'Inside the Tent: Community and Government in Refugee Camps'. Security Dialogue 45(1): 63-80.

CHAMBERS, R. (1986) 'Hidden Losers? The impact of rural refugees and refugee programs on poorer hosts'. International Migration Review 20(74): 245-263.

CHIMNI, B. S. (1993) 'The Meaning of Words and the Role of UNHCR in Voluntary Repatriation'. International Journal of Refugee Law 5(3): 442-460.

COLE, G. (2017) 'Beyond Labelling: Rethinking the Role and Value of the Refugee "Label" through Semiotics'. Journal of Refugee Studies 31(1): 1-21.

CRAWLEY, H. and SKLEPARIS, D. (2018) 'Refugees, migrants, neither, both: Categorical fetishism and the politics of bounding in Europe's "migration crisis". Journal of Ethnic and Migration Studies 44(1): 48-64.

CRISP, J. (2001) 'Mind the Gap! UNHCR, humanitarian assistance and the development process'. Working Paper No. 43, New Issues in Refugee Research. Geneva: UNHCR.

INHETVEEN, K. (2006) "'Because we are refugees": utilizing a legal label'. Working Paper No. 130, New Issues in Refugee Research. Geneva: UNHCR.

VAN DAMME, W., DE BROUWERE, V., BOELAERT, M. and LERBERGHE, W. (1998) 'Effects of a Refugee-Assistance Programme on Host Population in Guinea as Measured by Obstetric Interventions'. The Lancet 351(9116): 1609-1613.

DELANTY, G. (2003) Community. London: Routledge.

FERGUSON, J. (1994) The Anti-politics Machine: 'Development,'Depoliticization, and Bureaucratic Power in Lesotho. London: University of Minnesota Press.

FIDDIAN-QASMIYEH, E., RUIZ, I., VARGAS-SILVA, C. and ZETTER, R. (2012) Assessing the Impacts and Costs of Forced Displacement, Volume I: A Mixed Methods 
Approach. Washington, DC: World Bank Group. http://documents.worldbank.org/curated/en/447611467999137336/A-mixed-methodsapproach (accessed 15 July 2019).

FIDDIAN-QASMIYEH, E. (2016) 'Refugees Hosting Refugees'. Force Migration Review 53: $25-28$.

GENGO, R. G., OKA, R. C., VEMURU, V., GOLITKO, M. and GETTLER, L. T. (2017) 'Positive effects of refugee presence on host community nutritional status in Turkana County, Kenya', American Journal of Human Biology e23060, https://doi.org/10.1002/ajhb.23060 (accessed 15 July 2019).

GESCHIERE, P. (2009) The Perils of Belonging: Autochthony, Citizenship, and Exclusion in Africa and Europe. London: University of Chicago Press.

GOULD, W. T. S. (1974) 'Refugees in Tropical Africa'. International Migration Review, 8(3): 413-430.

GRINDHEIM, K. A. (2013) 'Exploring the impacts of refugee camps on host communities: a case study of Kakuma host community in Kenya'. Masters thesis, University of Agder.

HYNDMAN, J. (2000) Managing Displacement: Refugees and the Politics of Humanitarianism. Minneapolis: University of Minnesota Press.

INTERNATIONAL FINANCE CORPORATION (2018) Kakuma as a Marketplace. Washington DC.

JACOBSEN, K. (1997) 'Refugees' Environmental Impact: The Effect of Patterns of Settlement'. Journal of Refugee Studies 10(1): 19-36.

JACOBSEN, K. (2002) 'Can Refugees Benefit the State? Refugee Resources and African State Building', Journal of Modern African Studies 40(4): 577-596.

JAMAL, A. (2000) 'Minimum standards and essential needs in a protracted refugee situation: A review of the UNHCR programme in Kakuma, Kenya'. Geneva: UNHCR Evaluation and Policy Analysis Unit, http://www.unhcr.org/3ae6bd4c0.html (accessed 15 July 2019).

JANSEN, B. J. (2018) Kakuma Refugee Camp: Humanitarian Urbanism in Kenya's Accidental City. London: Zed Books.

JONSSON, E. (2016) Host community and refugees: a healthy relationship? Field study on the effects of the refugee influx on the host community in Kakuma, Kenya. Bachelors thesis, Linnaeus University.

KENYA HUMAN RIGHTS COMMISSION (2010) Foreigners at Home: The Dilemma of Citizenship in Northern Kenya.

KUHLMAN, T. (1990) Burden or Boon? A Study of Eritrean Refugees in the Sudan. Amsterdam: Free University Press.

KUMSA, M. K. (2006) “"No! I'm Not a Refugee!”: The Poetics of Be-Longing among Young Oromos in Toronto'. Journal of Refugee Studies 19(2): 230-255.

KURIMOTO, E. (2009) 'Changing Identifications among the Pari Refugees in Kakuma', in Schlee, G. and Watson, E. E. (eds) Changing Identifications and Alliances in North-East Africa, Volume II: Sudan, Uganda, and the Ethiopia-Sudan Borderlands. Oxford: Berghahn Books, pp. 219-234.

LANDAU, L. B. (2003) 'Beyond the Losers: Transforming governmental practice in refugeeaffected Tanzania'. Journal of Refugee Studies 16(1): 19-43.

LUDWIG, B. (2016) “"Wiping the Refugee Dust from My Feet”: Advantages and Burdens of Refugee Status and the Refugee Label'. International Migration 54(1): 5-18.

MALKKI, L. (1992) 'National Geographic: The Rooting of Peoples and the Territorialization of 
National Identity Among Scholars and Refugees'. Cultural Anthropology 7(1): 24-44.

MARTIN, A. (2005) 'Environmental Conflict Between Refugee and Host Communities'. Journal of Peace Research 42(3): 329-346.

MAZOU, R. (2017) 'Using socio-economic analysis to inform refugee programming in Turkana, Kenya'. World Bank Blog: Development for Peace, 10 February, http://blogs.worldbank.org/dev4peace/using-socio-economic-analysis-inform-refugeeprogramming-turkana-kenya (accessed 12 May 2018).

OMATA, N. (2019) "“Over-Researched" and "under-Researched"' Refugees. Forced Migration Review 61: 15-18.

ORACH, C. G. and DE BROUWERE, V. (2004) 'Postemergency health services for refugee and host populations in Uganda, 1999-2002'. Lancet 364(9434): 611-612.

PITTAWAY, E. and PITTAWAY, E. (2004) "“Refugee woman”: a dangerous label'. Australian Journal of Human Rights 10: 119-135.

RAMBO, A T., TINKER, J. M. and LENOIR, J. D. (1967) The Refugee Situation in Phu-Yen Province, Viet-Nam. McLean, VA: Human Sciences Research, Inc.

RICHMOND, A. (1994) Global Apartheid: Refugees, Racism, and the New World Order. Oxford: Oxford University Press.

RIOBA, B. (2017) 'Kitchen gardens cultivate bond between refugees, Kenyan hosts'. Reuters, 17 August, https://www.reuters.com/article/us-kenya-refugees-environment-water/kitchengardens-cultivate-bond-between-refugees-kenyan-hosts-idUSKCN1AX0AW (accessed 15 July 2019).

ROSE, N. (1999) Powers of Freedom: Reframing Political Thought. Cambridge: Cambridge University Press.

SAJJAD, T. (2018) 'What's in a Name? "Refugees", "Migrants" and the Politics of Labelling'. Race and Class 60(2): 40-62.

SANGHI, A. (2015) 'The Peculiar Economics of a Refugee Camp: "Yes in my backyard"' Brookings Blog, 25 March, https://www.brookings.edu/blog/futuredevelopment/2015/03/25/the-peculiar-economics-of-a-refugee-camp-yes-in-my-backyard/ (accessed 30 June 2018).

SANGHI, A., ONDER, H. AND VEMURU, V. (2016) 'Yes' in My Backyard? The Economics of Refugees and Their Social Dynamics in Kakuma, Kenya. Washington DC: World Bank.

SCOTT, J. (1998) Seeing Like a State: How Certain Schemes to Improve the Human Condition Have Failed. London: Yale University Press.

SHACKNOVE, A. E. (1985) 'Who Is a Refugee?' Ethics 95(2): 274-284.

SIGONA, N. (2003) 'How Can a "Nomad" be a "Refugee"? Kosovo Roma and Labelling Policy in Italy'. Sociology 37(1): 69-79.

TUMEN, S. (2016) 'The Economic Impact of Syrian Refugees on Host Countries: Quasiexperimental Evidence from Turkey'. American Economic Review 106(5): 456-460.

TURETI, M. K. (2003) 'The Impact of Refugees on Host Communities: The case of Kakuma Refugee Camp, Northwestern Kenya, 1992-2002'. MA thesis, University of Nairobi (Department of History).

TURTON, D. (2003) Conceptualising Forced Migration. RSC Working Paper No. 12, https://www.rsc.ox.ac.uk/files/files-1/wp12-conceptualising-forced-migration-2003.pdf (accessed 12 July 2019).

TURTON, D. (2005) 'The Meaning of Place in a World of Movement: Lessons from Long-term Field Research in Southern Ethiopia'. Journal of Refugee Studies 18(3): 258-80. 
UNHCR (2018) Kalobeyei Integrated Socio-Economic Development Plan in Turkana West: Phase One (2018-2022).

VEMURU, V., OKA, R., GENGO, R. and GETTLER, L. (2016) Refugee Impacts on Turkana Hosts: A Social Impact Analysis for Kakuma Town and Refugee Camp. Washington DC: World Bank.

WATERS, T. (1999) 'Assessing the Impact of the Rwandan Refugee Crisis on development Planning in Rural Tanzania, 1994-1996'. Human Organisation 58(2): 142-152.

WHITAKER, B. E. (2002) 'Refugees in Western Tanzania: The distribution of burdens and benefits among local hosts'. Journal of Refugee Studies 15(4): 339-358.

WHITAKER, B. E. (2005) 'Citizens and Foreigners : Democratization and the Politics of Exclusion in Africa'. African Studies Review 48(1): 109-126.

ZETTER, R. (1988) 'Refugees and Refugee Studies - a label and an agenda'. Journal of Refugee Studies 1(1): 1-6.

ZETTER, R. (1991) 'Labelling Refugees: Forming and Transforming a Bureaucratic Identity'. Journal of Refugee Studies 4(1): 39-62.

ZETTER, R. (2007) 'More labels, fewer refugees: Remaking the refugee label in an era of globalization'. Journal of Refugee Studies 20(2): 172-192. 